\title{
How will their airways be? Respiratory health 15 years after the start of apprenticeship
}

\author{
Katja Radon
}

Workplace exposures to dusts and chemicals in industrialised countries continue to decrease overall (while they remain constant or are even increasing in the developing world). However about 10\%$25 \%$ of asthma morbidity in adulthood is still estimated to be associated with occupational exposures. ${ }^{1}$ Exposures to high molecular weight occupational allergens such as animal antigens, flour, grain dust, and latex and their relevance to health have been extensively studied in the past ${ }^{2-4}$ and prospective cohort studies on this topic have also been published. ${ }^{5} 6$ What has not yet been prospectively studied over a long period is the association between low molecular weight allergen and irritant exposures and their association with respiratory health in young adults followed from the start of their professional life well into adulthood. ${ }^{7}$ So far general population cohort studies and studies among specific trades have indicated that these exposures also contribute to the burden of asthma and rhinitis in adulthood. ${ }^{1}{ }^{6-12}$ However as they were mainly confined to small numbers in specific trades or only followed participants for a short period of time knowledge about long-term outcome is limited. Such knowledge is nevertheless important when it comes to career coun-

Unit for Occupational and Environmental Epidemiology \& NetTeaching Institute and Outpatient Clinic for Occupational, Social and Environmental Medicine, Ludwig-Maximilians-University Hospital Munich Germany

Correspondence to Professor Dr Katja Radon Ludwig-Maximilians-University Hospital, Ziemssenstr. 1, Munich D-80336 Germany; Katja.Radon@med.Imu.de selling before and during the first years of employment.

In this issue of OEM (see page 237) Peters and colleagues present the results of such a prospective cohort study which they started in 1988. They followed almost 300 trainees of different British Columbian trade schools (construction, painters, electricians, insulator and machinist apprentices) over a 15-year period. ${ }^{13}$ Participants were first followed actively over 2 years while later on data were retrieved from routine registers the British Columbia Linked Health Database. During the first years of follow-up 16 participants were defined as having asthma and 20 were defined as having respiratory symptoms not suggestive of asthma. During the next 13 years outcome was defined based upon the number of physician visits due to respiratory complaints and new asthma/respiratory disease diagnosis. After 13 years the most robust predictor for the outcome under study was a rapid increase in unspecific bronchial responsiveness over the first 2 years of professional life. Bronchial responsiveness at baseline and the development of early symptoms were also associated with the number of physician visits. Based on the type of trade examined the authors suspect that metal-working fluids caused these symptoms. This finding supports data from cross-sectional studies and population-based register data. ${ }^{12} 14$

The results are in line with recent findings in Quebec $^{5}$ as well as German results $^{6}$ indicating that the first months of employment are important for long-term respiratory morbidity. Whereas sensitisation might be a major predictor of allergic asthma to high-molecular weight agents, ${ }^{5}$ unspecific bronchial hyper-responsiveness (BHR) might be more relevant for exposure to low-molecular weight agents and irritants. ${ }^{13}$ These studies provide evidence that surveillance as well as thorough career counselling and instruction on personal protection during the first months of occupational exposure are of the utmost importance to prevent occupational asthma. One may recommend that surveillance should be carried out at 6-month intervals during the first year of employment/training and on an annual base thereafter. ${ }^{6}$

We have however to take into account that the positive predictive value of a rapid increase in BHR remains low; in the current study only $25 \%$ of asthma patients would have been identified using this approach. ${ }^{13}$ Likewise the positive predictive value of BHR at baseline-the strongest predictor of new sensitisation to work-related allergens and incident chest symptoms in the study of Gautrin and colleagues $^{5}$-had positive predictive values of below 25\%. Nevertheless limiting surveillance programs to those workers with a rapid increase in BHR during the first months of employment would decrease the number of subjects in screening programs by more than $90 \%$. This would save costs and time as performing a large number of unspecific BHR tests might be challenging in daily practice for an enterprise/occupational physician but some subjects who would later develop respiratory symptoms might still be missed. Nevertheless the high negative predictive value (96\%) seems to make this approach ethically acceptable. More evidence however would be needed before reaching a conclusion as the number of cases in this study was small limiting the power of the study. An additional concern is that participants were informed about their individual test results during the first 2 years of the study. While this of course is ethically correct it might influence their healthcare utilisation pattern later on. Furthermore the authors did not verify whether participants stayed in the same job over time 
and thus remained exposed. However if the first job is the best predictor for asthma onset then this limitation might be less relevant for the results of the study. ${ }^{15}$

Taken together there is still little evidence that pre-employment screening efficiently reduces occupational and workrelated asthma or respiratory disease in the long term. More evidence is needed on exposures of apprentices over the first months of employment and on the evaluation of focused surveillance programs on those who may benefit the most. Further studies on apprentices exposed to low-molecular weight agents are currently underway and will hopefully support these findings. 716

\section{Competing interests None}

Provenance and peer review Commissioned; not externally peer reviewed

Occup Environ Med 2010;67:219-220.

doi:10.1136/oem.2009.047738

\section{REFERENCES}

1. Kogevinas M, Zock JP, Jarvis D, et al. Exposure to substances in the workplace and new-onset asthma: an international prospective population-based study (ECRHS-II). Lancet 2007;370:336-41.

2. Malo JL, Chan-Yeung M. Agents causing occupational asthma. J Allergy Clin Immunol 2009; 123:545-50.

3. Smith AM, Bernstein DI. Management of workrelated asthma. J Allergy Clin Immunol 2009;123:551-7.

4. Dykewicz MS. Occupational asthma: current concepts in pathogenesis diagnosis and management. J Allergy Clin Immunol 2009;123:519-28; quiz 29-30.

5. Gautrin D, Ghezzo H, Infante-Rivard C, et al. Longterm outcomes in a prospective cohort of apprentices exposed to high-molecular weight agents. $A m \mathrm{~J}$ Respir Crit Care Med 2008;177:871-9.

6. Riu E, Dressel H, Windstetter D, et al. First months of employment and new onset of rhinitis in adolescents. Eur Respir J 2007;30: 549-55.

7. Dragos $\mathbf{M}$, Jones M, Malo JL, et al. Specific antibodies to diisocyanate and work-related respiratory symptoms in apprentice car-painters. Occup Environ Med 2009;66:227-34.

8. Wiebert $\mathbf{P}$, Svartengren $\mathbf{M}$, Lindberg $\mathbf{M}$, et al. Mortality morbidity and occupational exposure to airway-irritating agents among men with a respiratory diagnosis in adolescence. Occup Environ Med 2008;65:120-5

9. Thaon I, Wild P, Mouchot L, et al. Long-term occupational consequences of asthma in a large
French cohort of male workers followed up for 5 years. Am J Ind Med 2008;51:317-23.

10. Mirabelli MC, Zock JP, Plana E, et al. Occupationa risk factors for asthma among nurses and related healthcare professionals in an international study. Occup Environ Med 2007:64:474-9.

11. Mirabelli MC, Zock JP, Plana E, et al. Employment status and use of respiratory protection among metalworkers solderers and welders. Occup Environ Med 2007;64:548-52.

12. Bakerly ND, Moore VC, Vellore AD, et al. Fifteen year trends in occupational asthma: data from the Shield surveillance scheme. Occup Med (Lond) 2008;58:169-74.

13. Peters CE, Demers PA, Sehmer J, et al. Early changes in respiratory health in trades' apprentices and physician visits for respiratory illnesses later in life. Occup Environ Med 2009 Aug 9. [Epub ahead of print].

14. Rosenman KD. Asthma hypersensitivity pneumonitis and other respiratory diseases caused by metalworking fluids. Curr Opin Allergy Clin Immunol 2009;9:97-102.

15. Benke G, Sim MR, McKenzie DP, et al. Comparison of first last and longest-held jobs as surrogates for all jobs in estimating cumulative exposure in crosssectional studies of work-related asthma. Ann Epidemiol 2008;18:23-7.

16. El-Zein M, Malo JL, Infante-Rivard C, et al. Incidence of probable occupational asthma and changes in airway calibre and responsiveness in apprentice welders. Eur Respir J 2003;22:513-18. 
OEM

How will their airways be? Respiratory

health 15 years after the start of apprenticeship

Katja Radon

Occup Environ Med 2010 67: 219-220

doi: 10.1136/oem.2009.047738

Updated information and services can be found at:

http://oem.bmj.com/content/67/4/219.full.html

These include:

References This article cites 15 articles, 8 of which can be accessed free at: http://oem.bmj.com/content/67/4/219.full.html\#ref-list-1

Email alerting Receive free email alerts when new articles cite this article. Sign up in service the box at the top right corner of the online article.

Notes

To request permissions go to:

http://group.bmj.com/group/rights-licensing/permissions

To order reprints go to:

http://journals.bmj.com/cgi/reprintform

To subscribe to BMJ go to:

http://group.bmj.com/subscribe/ 